\title{
Panner disease
}

INSERM

\section{Source}

INSERM. (1999). Orphanet: an online rare disease and orphan drug data base. Panner

disease. ORPHA:97336

Panner's disease is an osteochondrosis of the capitellum of the humerus, characterised by involvement of the dominant upper limb and onset before the age of 10 years. It results from lateral compression injuries of the elbow typically occurring in children practising sports such as baseball and throw. It should be disting uished from osteochondritis dissecans of the capitellum (see this term), occurring later, in adolescents. Management is symptomatic and consists in reducing the activities of the affected elbow for a prolonged period of time. Prognosis is good. 